\title{
Lagrange 表記による二次元波動の数值解析* NUMERICAL ANALYSIS OF TWO-DIMENSIONAL WAVE MOTION USING LAGRANGIAN DESCRIPTION
}

\author{
西村仁嗣**・武若 聡*** \\ By Hitoshi NISHIMURA and Satoshi TAKEWAKA
}

\begin{abstract}
The Lagrangian coordinate system has a notable advantage in the description of surface conditions which essentially prescribe the dynamics of water waves, although some difficulties are involved in numerical solution of equations. In this context, two alternative schemes (velocity and pressure formulations) are presented for analyzing twodimensional transformation of water waves. Their usefulness is examined through application to the resonant behavior of sloshing waves as well as to the breaking of a solitary wave.
\end{abstract}

Keywords: Lagrangian coordinate system, numerical analysis, two-dimensional wave transformation

\section{1. 緒言}

断面二次元の水面波動に対してはこれまでに数多くの 数值解析手法が提案されている. 特に Longuet-Higgins ら ${ }^{4}$ によって創始された一連の境界積分法 (Boundary Integral Method) はある程度の成果をあげ, 1 つの確 立された手法となっている $\left(\right.$ Peregrine $\left.^{5)}\right)$ 。さらに改良 $\mathrm{MAC}$ 法 $^{6}$ ， $\mathrm{FEM}^{71}$ など技巧的な計算手法も発表されて いるが, 非線形波動の解析におけるその実用性は必ずし も十分とはいえない.

支配方程式の記述に Euler 座標系を用いた場合, 非 線形の表面条件の扱いに特別の処理を施す必要がある. 水面波動においては自由表面の境界条件が現象全般を特 徵づける要因であり, 数値計算ではその簡便かつ適切な 扱いが望ましい。こうした観点から著者らは Lagrange

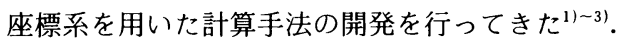

Lagrange 流の計算は 1970 年代初頭に発表された一 連の研究 ${ }^{81,91}$ に始まる. しかしながら, 当時は解法の不備, 計算機の演算容量, 速度面の制限等のために十分な成果

* 本論文は文献 1),2) の研究を発展させたものであり，そ の輪郭は文献 3) に述べられている.

** 正会員 工博 筑波大学助教授 構造工学系 ( テ305 つくば市天王台)

*** 学生会員 工修 筑波大学大学院工学研究科 (同上)
を挙げるには至らなかった。1975 年には $\mathrm{Chan}^{10)}$ が在来 の研究を統合し，問題点の整理をした。ただし，計算に 緩和法を用いたために精度上の問題が残り，有用な結果 を得るには人工的な抵抗項を加える必要があった。これ らの点をふまえて著者らは implicitな解法を導入し， 精度の向上を図った.

本論文では従来の計算方法の応用範囲を拡張し，さら に計算所要時間の大幅な短縮を可能とする新たな計算方 式を提示する．計算例としては斜面上の孤立波の砕波点 までの浅水変形を扱い, それぞれの手法の利点および欠 点を論じる.

\section{2. 支配方程式系の Lagrange 表記}

非粘性・非圧縮性流体の鉛直二次元の波動を考え，物 理平面内に固定された座標系として水平方向に $X$ 軸, 鉛直方向に $Y$ 軸をとる. ある流体粒子の位置ベクトル を $\boldsymbol{Z}(X, Y)$ と書けば, 運動方程式および連続式は Lagrange 座標系で次のように記述される。

$$
\begin{aligned}
& \left(\boldsymbol{Z}_{t t}+\boldsymbol{H}\right) \cdot \boldsymbol{Z}_{a}=-P_{a} / \rho \\
& \left(\boldsymbol{Z}_{t t}+\boldsymbol{H}\right) \cdot \boldsymbol{Z}_{b}=-P_{b} / \rho \\
& X_{a} Y_{b}-X_{b} Y_{a}=J \cdots \cdots \cdots
\end{aligned}
$$

ここに, $t$ は時間, $(a, b)$ は流体粒子を識別する Lagrange 変数の組であり, 添字は偏微分を表わすものとす 
る. $J$ は時間によらない関数である.また, $\boldsymbol{H}$ は外力 の加速度, $P$ は圧力, $\rho$ は流体の密度である.

以下においては, 便宜上 Lagrange 変数として基準時 刻 $t=0$ における粒子の位置座標 $(X, Y)$ をとることに する.このとき自由表面の流体粒子は $a-b$ 平面上の直 線 $b=b_{0}$ で表わされる. そこで水表面における力学的 境界条件は

$$
P=0 \text { on } b=b_{0} \cdots
$$

あるいは $\boldsymbol{Z}$ を用いて

$$
\left(\boldsymbol{Z}_{t t}+\boldsymbol{H}\right) \cdot \boldsymbol{Z}_{a}=0 \text { on } b=b_{0}
$$

と書かれる。

運動学的な境界条件としては, ある境界上の流体粒子 が常にその境界上に存在することが要求される．仮に境 界形状が曲線で与えられ，あるいはそれが時間的に変動 する場合でも, Lagrange 流の取扱いにおいては $(a, b)$ 座標系の任意性を利用して比較的容易にこれに対処する ことができる.すなわち，境界に沿ってとられた $a$ も しくは $b$ の一定値に対して, 物理座標 $(X, Y)$ にる境 界形状の表記そのものがこれらの未知量の満たすべき条 件式である。

Euler 座標系で同じ問題を定式化すると, 自由表面で の 2 つの境界条件はともに非線形となる. これに対して Lagrange 座標系での表面条件は式 (4) あるいは式 (5) のみであり, 大幅に簡単化されている，水面波動におい ては表面近傍の水理が現象全般を強く支配するので, 表 面条件の取扱いを容易とすることは解析に際して大いに 有利である.しかしながら，その代償として次のような Lagrange 表記固有の問題点が生じる.

(1) 運動方程式ならびに連続式はともに非線形であ り，水粒子の位置を変数とするために方程式系が時 間に関して 2 階の微分項を含むことになる。

（2) 粒子位置を正確に算定するために，速度，加速度 の水平および鉛直成分を同じ点で計算することが望 ましい. したがって, 流れの場の解析に際して最も 合理的と思われる staggered scheme が適用できな い.

これらはいずれも数値解析の困難ならびに精度低下を もたらし得る要因である.

\section{3. 速度解法}

ここでは流速 $\boldsymbol{W}(U, V)$ を主な未知量とする計算法に ついて述べる11,2).この方法の基本的な考え方は各時間 ステップにおいて，連続式，非回転条件式および各境界 条件を満たすように流速成分を定め, その積分によって 新たな粒子位置を求めるものである，運動方程式の時間 積分を 1 回解析的に行うので，時間に関する数值積分は 1 回でよい.
$\boldsymbol{H}$ が時間のみの関数である場合，すなわち保存力の 場の運動に関しては, 運動方程式（1）および（2）か ら圧力 $P$ を消去することが可能となり

$$
U_{a} X_{b}-U_{b} X_{a}+V_{a} Y_{b}-V_{b} Y_{a}=C
$$

を得る。これは渦度の保存を示す式であり， $C$ は時間 によらない関数である. 非回転運動に対しては $C$ は 0 である. 一方, 連続式（3）を時間について偏微分する と

$$
U_{a} Y_{b}-U_{b} Y_{a}-V_{a} X_{b}+V_{b} X_{a}=0
$$

を得る.さらに表面条件式（5）を同様の表示に改める と

$$
\left(U_{t}+F\right) X_{a}+\left(V_{t}+G\right) Y_{a}=0 \text { on } b=b_{0}
$$

となる.ここに $F$ および $G$ は外力加速度 $\boldsymbol{H}$ の各方向 成分である．固体壁での境界条件は法線方向の速度を 0 にすることによって満たされる．流体粒子位置と速度は 自明の関係式

$$
X_{t}=U, \quad Y_{t}=V
$$

で結ばれている.

以下の各項では式（6)（9）の方程式系を時間発展 的な境界值問題として解くための具体的な方法について 述べ

\section{（1）計算格子}

数值計算を行うにあたり，未知量 $\boldsymbol{W}$ および $\boldsymbol{Z}$ を時間 的，空間的に離散化する必要がある. Fig. 1 に示すよう な初期空間 $(a, b)$ において方形格子を設定し, 各格子 点で $\boldsymbol{W}, \boldsymbol{Z}$ の值を定義することにより空間的な離散化 を行う. 以下においては, 説明の便宜上 $a, b$ 方向の格 子間隔を等しく $\Delta s$ とし, 格子点 $(i \Delta s, j \Delta s)$ における 値を $\boldsymbol{W}_{i, j}$ のように表現する $(i=0, \cdots, m ; j=0, \cdots, n)$. ただし，表面条件の差分について若干の注意を払えば， 格子間隔を非一様としても取扱い上の差異を生じないこ とが後に明らかにされる，変則的な計算格子を容易に導 入し得ることは非一様な流れの場の取扱いに際して，本 手法の大きな利点となる。

時間的な離散化は $\boldsymbol{W}, \boldsymbol{Z}$ について互いに半格子だけ ずらし， $\boldsymbol{W}_{i, s}$ を計算ステップ $t=k \Delta t, \boldsymbol{Z}_{i, s}$ を計算ステッ プ $t=(k+1 / 2) \Delta t$ で定義するのが便利である（ $k=0$,

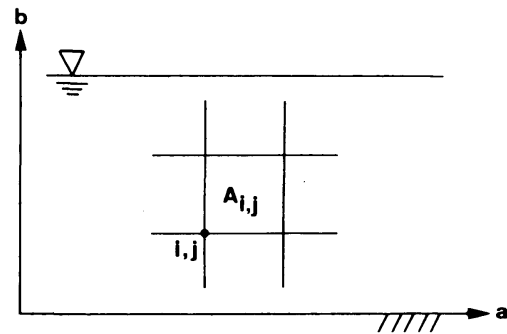

Fig. 1 Grid scheme (Velocity formulation). 
$1, \cdots)$. ここに, $\Delta t$ は時間刻みである.

通常の数值計算では, staggered scheme を用いるこ とにより離散化された拘束条件（支配方程式および境界 条件) の合計数と末知量の個数を合理的に一致させるこ とが可能である. いま, 各計算セルの中心を節点とし, その各辺を横切る状態の管路網で流れの場を近似すると き, staggered schemeにおける計算点配列はこのモデ ルのかなり厳密な表現となっている.これに対して Lagrange 座標系では, 流体粒子の変位と流速が式（9） で直接に関連付けられ，同一点で計算される。このよう な計算点配列では離散化された拘束条件と末知量の個数 を一致させることは困難である，この場合には，上述の ような物理モデルは介在し得ず, 離散化された諸量は単 に連続的な流速および圧力の分布を代表するものとな る.そこでは近接する計算值間の大きな変動は本来許さ れないので,一部の条件式を除外するなどの処置をとり, これが計算結果に大きく影響しないことを期待せざるを 得ない。

\section{（2）方程式系の差分表示}

支配方程式および境界条件式はいずれも，中央差分近 似により差分方程式に変換される. まず, 式（9）は

$$
\boldsymbol{Z}_{i, j}^{k+1}=\boldsymbol{Z}_{i, j}^{k}+\boldsymbol{W}_{i, j}^{k+1 / 2} \Delta t
$$

ここで $k$ 等は計算ステップを表わす。

同様に, 式 (6) は Fig. 1 中のセル中央の点について 差分をとることにより

$$
\begin{aligned}
& \left(U_{i+1, J+1}^{*}-U_{i, j}^{*}\right)\left(X_{i, J+1}-X_{i+1, j}\right) \\
& \quad-\left(U_{i, J+1}^{*}-U_{i+1, j}^{*}\right)\left(X_{i+1, j+1}-X_{i, J}\right) \\
& \quad+\left(V_{i+1, J+1}^{*}-V_{i, j}^{*}\right)\left(Y_{i, J+1}-Y_{i+1, J}\right) \\
& \quad-\left(V_{i, J+1}^{*}-V_{i+1, j}^{*}\right)\left(Y_{i+1, j+1}-Y_{i, j}\right)=0 .
\end{aligned}
$$

となる.ただし*は計算ステップ $t=(k+1 / 2) \Delta t$ での 値を表わす. 上式は, 計算ステップ $t=(k+1 / 2) \Delta t$ の 流速を決定するための方程式であるが, 式中の $X$ およ び $Y$ は計算ステップ $t=k \Delta t$ の值によって近似する. ここでは式（6）を形式的に差分化することによって上 式を得たが, 同一の表示は任意の形状のセルについて循 環の保存を考えることによっても得られる. したがって 不等間隔の計算格子にも容易に対応することができる.

流体の非圧縮性を考えると, 物理平面内における各計 算セルの面積は運動の過程で一定に保たれなければなら ない. 時刻 $t=k \Delta t$ における Fig. 1 中のセル $(i, j)$ の面 積 $A_{i, j}$ は,

$$
\begin{aligned}
2 A_{i, j}^{k}= & \left(X_{i+1, j+1}^{k}-X_{i, j}^{k}\right)\left(Y_{i, J+1}^{k}-Y_{i+1, j}^{k}\right) \\
& -\left(X_{i, j+1}^{k}-X_{i+1, j}^{k}\right)\left(Y_{i+1, j+1}^{k}-Y_{i, j}^{k}\right)
\end{aligned}
$$

である. 1 ステップの流体運動による面積の変化率は

$$
\begin{aligned}
2\left(A_{t}\right)_{i, j}^{*}= & \left(U_{i+1, j+1}^{*}-U_{i, j}^{*}\right)\left(Y_{i, j+1}-Y_{i+1, j}\right) \\
& -\left(U_{i, j+1}^{*}-U_{i+1, j}^{*}\right)\left(Y_{i+1, j+1}-Y_{i, j}\right) \\
& -\left(V_{i+1, j+1}^{*}-V_{i, j}^{*}\right)\left(X_{i, j+1}-X_{i+1, j}\right)
\end{aligned}
$$

$$
+\left(V_{i, j+1}^{*}-V_{i+1, j}^{*}\right)\left(X_{i+1, j+1}-X_{i, j}\right)
$$

となり，流速はこれが 0 となるように決定される.ここ でも， $X, Y$ は計算ステップ $t=k \Delta t$ での值によって近 似する.この近似による誤差の累積を防ぐために，実際 の計算においては, 流体運動の連続性を表わす条件式と して補正項を付加した次式を用いる.

$\left(A_{t}\right)_{i, j}^{*}+\left(A_{i, j}^{k}-A_{i, j}^{0}\right) / \Delta t=0 \cdots$

ここでも前式におけると同様, 格子間隔の不等性が支障 を生じることはない.

運動学的な境界条件は, 流速についてみると, 壁面に 対して垂直な流速成分を 0 とすることによって満たされ る. 壁面と底面が接合する隅点はよどみ点となる。

表面の力学的な境界条件式（8）は，Fig.2のような 不等間隔の計算格子について重み付き中央差分をとるこ とにより次のように書かれる.

$$
\begin{aligned}
& \left(U_{i, n}^{*}-U_{i, n}^{k-1 / 2}\right) X_{1}+\left(V_{i, n}^{*}-V_{i, n}^{k-1 / 2}\right) Y_{1}=-Z_{1} \Delta t \\
& X_{1}=F_{1} X_{i-1, n}^{k}+F_{2} X_{i, n}^{k}+F_{3} X_{i+1, n}^{k} \\
& Y_{1}=F_{1} Y_{i-1, n}^{k}+F_{2} Y_{i, n}^{k}+F_{3} Y_{i+1, n}^{k} \\
& Z_{1}=F_{i, n}^{k} X_{1}+G_{i, n}^{k} Y_{1} \\
& F_{1}=\left(\Delta s_{i-1} / \Delta s_{i}\right) /\left(\Delta s_{i-1}+\Delta s_{i}\right) \\
& F_{2}=\left(\Delta s_{i}-\Delta s_{i-1}\right) /\left(\Delta s_{i-1} \Delta s_{i}\right) \\
& F_{3}=\left(\Delta s_{i+1} / \Delta s_{i}\right) /\left(\Delta s_{i-1}+\Delta s_{i}\right)
\end{aligned}
$$

ここで $\Delta s_{i}$ は $t=0$ における表面上 $a$ 方向の格子間隔で ある.この表記は一般には表面上の計算点 $i \pm 1, i$ 間に 若干の相関を与えている，格子間隔を等しくとると，拘 束は計算点 $i-1, i+1$ 間のみのものとなる. 不等間隔 の計算格子を採用すれば隣接する計算点間の拘束が強化 され，これは後に述べるように計算の安定性を図るうえ である程度の意味をもっている.

\section{（3）計算手順ならびに問題点}

粒子位置 $\boldsymbol{Z}^{\boldsymbol{k}}$ が与えられたならば，新たな流速 $W^{\kappa+1 / 2}$ は式 (11)，(14）および境界条件より構成され る線形の連立方程式系から計算される。ここでは, 前項 の考察に基づき，表面と壁面の接合点における表面条件 を除外することにより拘束条件と末知量 $\boldsymbol{W}$ の数を一致 させた，引き続き，式（10）から新たな粒子位置 $\boldsymbol{Z}$ を 算定し，次のステップへと計算を進めることができる.

ここで扱う係数行列の主要部分は式 (11) および (13) から構成され，その形は対角項が絶対優位の形式とはな らない. したがって, 緩和法 (SOR あるいはCG) に より効率よく解くことは困難である. 実際には掃き出し

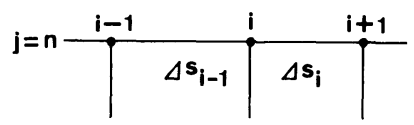

Fig. 2 Grid scheme at a free surface. 
法を用いたが，行列のサイズが大きくなると計算精度お よび所要時間の点で問題が生じるものと思われる.

また, 計算精度の低下あるいは格子変形の進行に伴い, alternating error あるいは checkerboard split と呼ばれ る計算上の不安定が生じがちである.これは $i+j$ が偶 数もしくは奇数となるような 2 組の格子点系列間のカッ プリングであり，その発生は差分式 (11) および (13) の形からも予見されるところである．高次の差分表示を 用いて両系列間の相関を強化することは 1 つの効果的な 対策かもしれないが, 計算労力の面で大きな負担となる. むしろ implicit な計算で精度を高め，あるいは式 (15) のような表面条件の定式化を通じてその抑制を図るのが 現実的である.

\section{4. 压力解法}

本節では圧力 $P$ を主たる末知量とする計算方式につ いて述べる。すなわち，圧力場が誘起する水粒子の加速 度を 2 回時間積分することにより算定される粒子位置 が，連続式を満たすように各点の圧力を決定する．この 方法は流体粒子が圧力勾配に応じて運動する様子を最も 直接的に表現しており，Euler 座標系の中で粒子の軌跡 を追う MAC 法の立場をさらに推し進めたものといえ る.必要ならば摩擦項等の導入に対しても比較的容易に 対応できる.

$\boldsymbol{H}$ を時間のみの関数とすると, 運動方程式（1）お よび（2）は

$$
\begin{aligned}
& X_{t t}=-Y_{b}(P / \rho+\boldsymbol{H} \cdot \boldsymbol{Z})_{a}+Y_{a}(P / \rho+\boldsymbol{H} \cdot \boldsymbol{Z})_{b} \\
& Y_{t t}=X_{b}(P / \rho+\boldsymbol{H} \cdot \boldsymbol{Z})_{a}-X_{a}(P / \rho+\boldsymbol{H} \cdot \boldsymbol{Z})_{b} \cdots
\end{aligned}
$$

と書き改められる。ただし， $(a, b)$ を流体粒子の初期位 置で定義したので， $J=1$ である. 上式の 2 重の時間積 分により得られる粒子位置が連続式

$$
X_{a} Y_{b}-X_{b} Y_{a}=1
$$

を満たすよう $P$ を決定する，自由表面における境界条 件は

$$
P=0 \text { on } b=b_{0} \cdots
$$

である。

\section{（1）計算格子}

前節におけると同様に， $P, \boldsymbol{W}$ および $Z$ を時間的， 空間的に離散化する.ここでは新たに加速度 $\boldsymbol{W}_{t}$ を導入 する. Fig. 3 に示すように初期空間 $(a, b)$ において方形 格子を設定し, 各格子点で $\boldsymbol{W}_{t}, \boldsymbol{W}$ および $\boldsymbol{Z}$ を定義する. $a, b$ 方向の格子間隔 $\Delta s$ は等しいものとし, 各格子点 $(i \Delta s, j \Delta s)$ での値を $\boldsymbol{W}_{t i, j}, W_{i, j}$ および $\boldsymbol{Z}_{i, j}$ で示す（ $i=$ $0,1, \cdots, m ; j=0,1, \cdots, n)$. 圧力 $P_{i, j}$ の值のみは, 七 ル中央の点 $((i+1 / 2) \Delta s,(j+1 / 2) \Delta s)$ で定義する

(Fig. 3).

時間的には $P, \boldsymbol{Z}$ および $\boldsymbol{W}_{t}$ を計算ステップ $t=k \Delta t$,
W の值を計算ステップ $t=(k+1 / 2) \Delta t$ において定義す る $(k=0,1,2, \cdots)$.

この計算格子では，1 つのセル中央の圧力が周囲 8 点 の圧力との関連で 4 つの隅点における粒子の運動を制す ることになり，その意味で staggered schemeに類似し ている.しかしながら，この場合にも離散化され方程式 と末知数の個数を一致させることは困難である.

\section{（2）方程式系の差分表示}

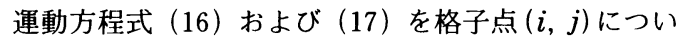
て差分化すると（Fig. 3)

$$
\begin{aligned}
& U_{i, j}^{k}=\left[-\left(Y_{i, j+1}-Y_{i, j-1}\right)\left(p_{i, j}-p_{i-1, j}+p_{i, J-1}-p_{i-1, J-1}\right)\right. \\
& \left.+\left(Y_{i+1, j}-Y_{i-1, j}\right)\left(p_{i, j}-p_{i, j-1}+p_{i-1, j}-p_{i-1, j-1}\right)\right] / \Delta s^{4} \\
& V_{t i, j}^{k}=\left[\left(X_{i, j+1}-X_{i, j-1}\right)\left(p_{i, j}-p_{i-1, j}+p_{i, j-1}-p_{i-1, j-1}\right)\right. \\
& \left.+\left(X_{i+1, j}-X_{i-1, j}\right)\left(p_{i, j}-p_{i, j-1}+p_{i-1, j}-p_{i-1, j-1}\right)\right] / \Delta s^{4}
\end{aligned}
$$

となる.ここで, $U_{t}$ および $V_{t}$ は $\mathbf{W}_{t}$ の各方向成分, $p$ $=P / \rho+\boldsymbol{H} \cdot \boldsymbol{Z}$ である. 粒子位置 $\boldsymbol{Z}$ と加速度 $\boldsymbol{W}_{t}$ の関係 は式（9）より

$$
\boldsymbol{Z}_{t t}=\boldsymbol{W}_{t}
$$

である。これに基づき，次式のように時間的な離散化を 行う.

$$
\begin{aligned}
\boldsymbol{Z}_{i, j}^{k+1} & =\boldsymbol{Z}_{i, j}^{k}+\left(\boldsymbol{W}_{i, j}^{k+1 / 2}\right) \Delta t \\
& =\boldsymbol{Z}_{i, j}^{k}+\left(\boldsymbol{W}_{i, j}^{k-1 / 2}+\boldsymbol{W}_{t i, j}^{k} \Delta t\right) \Delta t
\end{aligned}
$$

ここで， $k$ 等は計算ステップを表わす.

一方, 七ル $(i, j)$ の面積 $A_{i, j}$ は前節の表示式 (12) で 与えられる. 1 ステップの流体運動の後, $t=(k+1) \Delta t$ における面積は式 (21) を用いることにより

$$
\begin{aligned}
2 A_{i, j}^{k+1}= & \left(X_{i+1, j+1}^{k+1}-X_{i, j}^{k+1}\right)\left(Y_{i, j+1}^{k+1}-Y_{i+1, j}^{k+1}\right) \\
& -\left(X_{i, j+1}^{k+1}-X_{i+1, j}^{k+1}\right)\left(Y_{i+1, j+1}^{k+1}-Y_{i, j}^{k+1}\right) \\
= & \left(x_{i+1, j+1}-x_{i, j}\right)\left(y_{i, j+1}-y_{i+1, j}\right) \\
& -\left(x_{i, j+1}-x_{i+1, j}\right)\left(y_{i+1, j+1}-y_{i, j}\right) \\
& +\left(U_{t i+1, j+1}^{k}-U_{t i, j}^{k}\right)\left(y_{i, j+1}-y_{i+1, j}\right) \Delta t^{2} \\
& -\left(U_{t i, j+1}^{k}-U_{t i+1, j}^{k}\right)\left(y_{i+1, j+1}-y_{i, j}\right) \Delta t^{2} \\
& -\left(V_{t i+1, j+1}^{k}-V_{t i, j}^{k}\right)\left(x_{i, j+1}-x_{i+1, j}\right) \Delta t^{2} \\
& +\left(V_{t i, j+1}^{k}-V_{t i+1, j}^{k}\right)\left(x_{i+1, j+1}-x_{i, j}\right) \Delta t^{2}
\end{aligned}
$$

ここに,

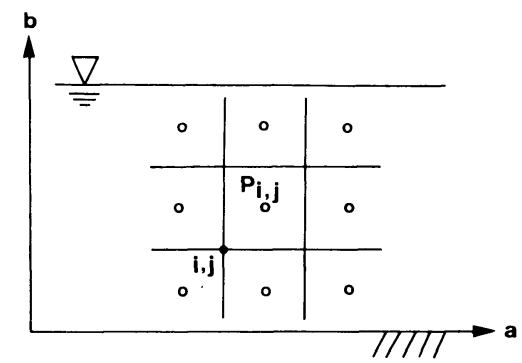

Fig. 3 Grid scheme (Pressure formulation) 
$z=z(x, y)=Z^{k}+W^{k-1 / 2} \Delta t$

となる.ただし $\Delta t^{4}$ 以上の高次項は省略した。連続式 としては

$$
A_{i, j}^{k+1}=A_{i, j}^{0}
$$

に式（18）および（19）を代入したものを用いる.こう して $p$ について書かれた連続式は Lagrange 座標系にお けるPoisson 方程式となる.

運動学的な境界条件は, 壁面に対して垂直な加速度成 分ならびに流速成分を 0 とすることによって満たされ る．壁面と底面の接合する隅点はよどみ点となる．表面 では力学的な境界条件により, 式（18）および（19）を 用いるときに圧力 $P$ を 0 とする.

Fig. 4 に示すような壁面上の計算点で，境界に沿う加 速度成分を決定するには, 計算領域外の圧力が必要とな る.この場合, 内部の圧力分布から必要な圧力を外挿す る方法を採用する. すなわち, 線形の変化を想定すると,

$$
P_{i+1, j}=-\lambda P_{i-1, j}+(1+\lambda) P_{i, j}
$$

となる (Fig. 4). $\lambda=1$ のときには $P$ は内部 2 点の圧力 分布を直線状に延長したことになり，また $\lambda=0$ のとき には壁面上の圧力として $P_{i, j}$ そのものを用いることにな る. 多くの場合， $\lambda=0$ の設定により妥当な結果が得ら れるようである.

\section{（3）計算手順および問題点}

粒子位置 $\boldsymbol{Z}^{\boldsymbol{k}}$ および流速 $\boldsymbol{W}^{\boldsymbol{k}-1 / 2}$ が与えられたならば, 圧力 $P^{k}$ は式 $(24)$ から構成される線形の連立方程式に 基づいて計算される。 その後，式（18）および（19）か ら加速度 $\boldsymbol{W}_{t}^{\boldsymbol{k}}$, 式 (21) から新たな粒子位置ならびに速 度を決定し，以下時間ステップごとに計算を進める.

ここで提示した圧力解法の最大の利点は, 速度解法に 比して扱う行列の次数がほぼ半減し，計算時間が大幅に 短縮されることである．また，対角成分が卓越する形の 行列亡なるので，その取扱いが比較的容易である.

一方，この方法に従って計算を行うと，流体の変形が 大きくなった時点で, 前述した計算格子間のカップリン グがより頻繁に発生する．同時に，非粘性の仮定の下の 計算においても渦度が発生し，累積する。その補正には，

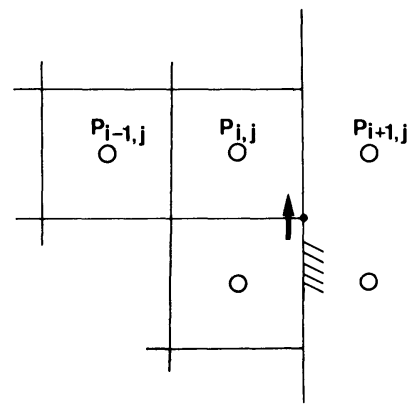

Fig. 4 Grid scheme at a rigid wall.
$\mathrm{Chan}^{10)}$ が流速成分を求めるために用いた緩和計算法が 有効である. 数ステップごとにこの操作を挿入すること によって計算の安定性が維持されるが，ここには多少の 経験的な要素が含まれる.

\section{5. 計 算 例}

本節では，鉛直二次元の波動解析に上述の計算手法を 応用し，その有用性を検討する。

（1） 方形タンク内のスロッシング

水平方向に振動する方形タンク内の水のスロッシング を考える. タンクとともに変位する移動座標系 $(X, Y)$ を採用すると，各壁面および底面はそれぞれ $X$ および $Y$ の一定值で表現される，調和的な振動に対して外力 加速度 $\boldsymbol{H}$ は

$$
\boldsymbol{H}=\left(-A_{0} \omega^{2} \sin \omega t,-g\right)
$$

となる.ここで $A_{0}$ は夕ンクの振幅， $\omega$ は振動の角周波 数, $g$ は重力加速度である.

想定された現象の諸元は次のとおりである.

$$
\begin{array}{ll}
\text { タンク幅員 } & 1.0 \mathrm{~m} \\
\text { 静水深 } & 0.6 \mathrm{~m} \\
\text { タンクの振幅 } & A_{0}=0.005 \mathrm{~m} \\
\text { タンクの振動周期 } & T=2 \pi / \omega=1.159 \mathrm{~s}
\end{array}
$$

上述の周期は，微小振幅波理論に基づく第 1 次モードの 重複波周期に相当するので，共振に近い波動を取り扱う ことになる．計算格子間隔を空間的には $a, b$ 方向同等 $に \Delta s=0.05 \mathrm{~m}$, 時間的には $\Delta t=T / 100$ とし, 静水状 態から始まるスロッシングの発達過程を試算した。

Fig. 5 に流体の変形と内部流速場を例示する. Fig. 6 は側壁における水位変動の状況を線形理論に基づく高山 の解析解 ${ }^{11)}$ と比較したものである。ただし計算結果は 4 $\Delta t$ ごとにプロットされている．計算された水位変動は 解析解に比していくぶん上方にずれているが，これは非 線形性の効果と考えられる.

流速解法, 圧力解法のいずれを用いても計算結果に有 意な差異は認められない。ただし後者においては 5 ない し10 ステップごとに渦度消去のための補正計算を行っ た. 流速解法で計算点数約 550,600 ステップまでの計 算に大型計算機システム $\mathrm{M}-780 / 20$ を用いておよそ 2 分 を要した。これは圧力解法における計算所要時間のほぼ 2 倍である。

\section{（2）孤立波の浅水变形}

水路端の鉛直壁を水平方向に変位させることによって 水路内に孤立波を発生させ，その伝幡状況を数值的にシ

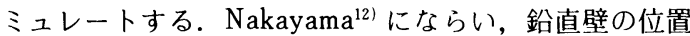
を次式のように与える.

$X(t)=B_{0} \tanh \left(\nu\left(t-t_{0}\right)\right)$ for $0<t<t_{e}$

いま $B_{0}=0.083 \mathrm{~m}, \nu=4.688 \mathrm{~s}^{-1}, \quad t_{0}=0.742 \mathrm{~s}, t_{e}=$ 
$1.485 \mathrm{~s}$ 等の条件を与え, 水平床上の孤立波の伝幡, な らびに水路他端の鉛直壁での反射を計算したところ,

Fig. 7 に示すような水位変動および流体要素の変形過程 が得られた。計算は速度解法, 圧力解法の双方を用いて 行われたが，ここでも両者の解の間に有意な差異は生じ ない. 計算刻みは $\Delta s=0.03 \mathrm{~m}, \Delta t=0.0015 \mathrm{~s}$ であり, 格子線数は水平方向に $m=54$, 鉛直方向に $n=5$ とした. 演算にはやはり高速計算機システム M-780/20を用いた
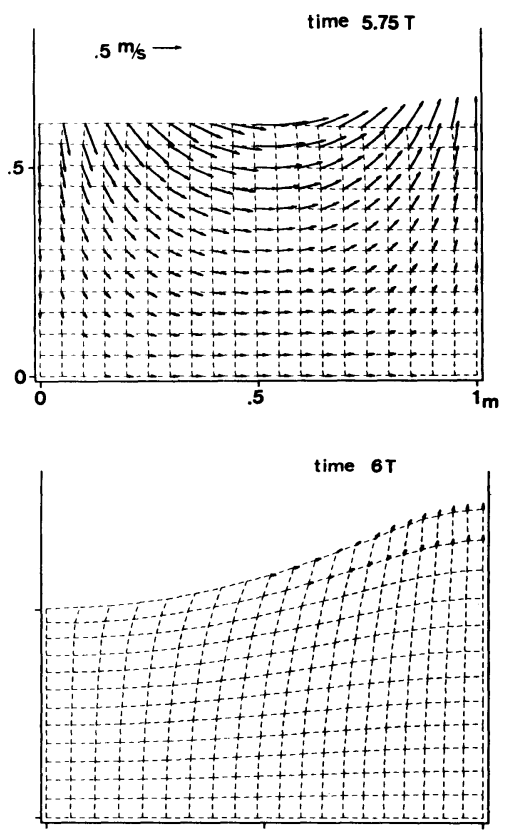

Fig. 5 Two-dimensional sloshing of water in a rectangular tank.
が，速度解法による 1800 ステップの計算におよそ 3 分 を要した．鉛直壁の前方変位のために波の通過後も特に 水面近傍に水粒子の前方変位が残存している.

次に $1 / 20$ 勾配斜面上における孤立波の砕波点近傍ま での浅水変形を解析した。ここでは不等間隔の計算格子 を用いるので，計算は流速解法によった，対象とした底 面地形を Fig. 8 に示す.造波板側に一様水深部を設けず, 直接斜面上から計算を開始する.この場合，初期の粒子 位置を適切に選ぶことにより，計算格子の過大な変形を 緩和することが可能になる，すなわち，表面および砕波 点近傍で格子が密となるよう以下の方法で計算点を配置 した.

(1) 水平格子線：最上端の格子線は静水面, 最下端の 格子線は底面に沿ってとり，この間の格子線の鉛直座標 は対数的に定める.

$$
Y_{i, j}-Y_{i, 0} \propto \log (1+\alpha j)
$$

ただし， $\alpha$ は格子線の鈆直間隔の不等性の度合を与える 係数である.

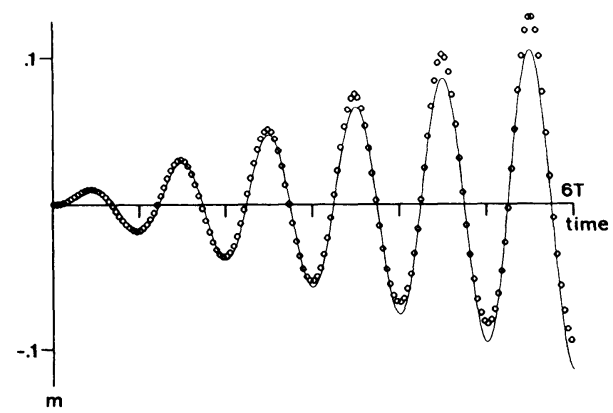

Fig. 6 Variation of surface elevation at a sidewall

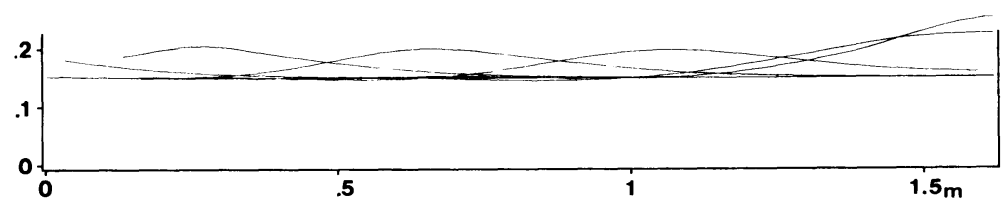

(a) Surface profiles at $t=0.3,0.6,0.9,1.2,1.5,1.8$ and $1.95 \mathrm{~s}$

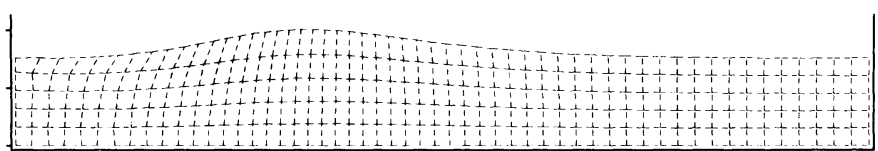

(b) Deformation of elements at $t=1.2 \mathrm{~s}$

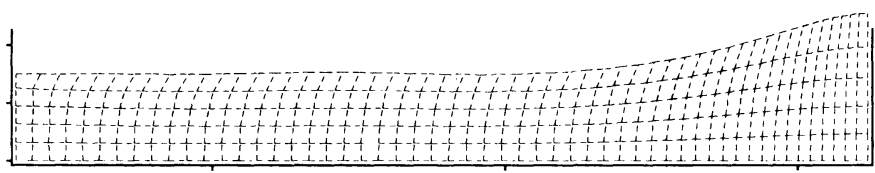

(c) Deformation of elements at $t=1.95 \mathrm{~s}$

Fig. 7 Propagation of a solitary wave. 
(2) 鉛直格子線：水路両端の格子線は鉛直壁に沿って とり, 中間の格子線の水平座標は次式によって定める.

$$
X_{i, j} \propto i-\beta i^{2}-\gamma j
$$

上式中の $\beta$ は格子点ごとの水平間隔の縮小量である. また， $\gamma$ として適宜な値を設定すると，格子線があらか じめ後方に湾曲した状態亡なるので, 水粒子の残存変位 による流体要素の偏平化が緩和される.

全長約 $2.4 \mathrm{~m}$, 沖側端での水深 $0.15 \mathrm{~m}$ の水路を想定 し, 格子線数は水平方向に $m=90$, 鉛直方向に $n=5$ 之 した. $\alpha=1.8, \beta=0.003, \gamma=0.125$ 等の係数值を用い ることにより，初期の格子形状はFig. 8 のようになる.
本計算における時間刻みは $\Delta t=0.62 \mathrm{~ms}$ である.また， 造波条件を $B_{0}=0.104 \mathrm{~m}$ とした以外は前例におけると 全く同様である.

Fig. 9 に波形および格子の変形過程を示す.Fig. 10 は 砕波直前の波形について, 計算結果をほぼ同一条件下に おける長尾 ${ }^{13)}$ の実験結果と比較したものである。最大波 高はほぼ一致するものの, 実験上の砕波初期と思われる 時点では計算は持続しており，いくぶん現実とは異なる 波形が得られている、さらに計算精度を点検する目的で 波の有する全エネルギーの経時変化を調べたところ，造 波終了時点以降その総量が良好に保存されることが確か
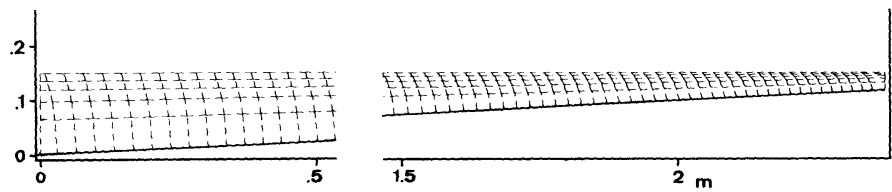

Fig. 8 Bottom configuration and grid scheme.

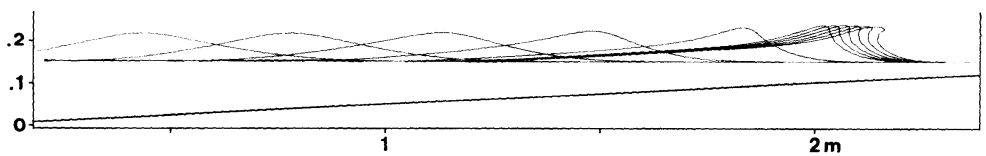

(a) Surface profiles at $t=0.99,1.24,1.45,1.74,1.98,2.11,2.12,2.14,2.15,2.17$ and $2.19 \mathrm{~s}$

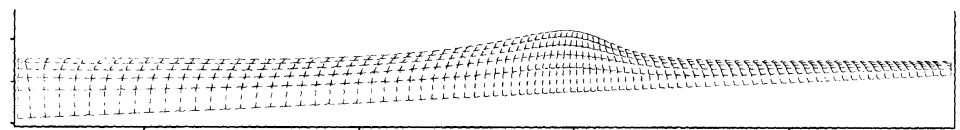

(b) Deformation of elements at $t=1.74 \mathrm{~s}$

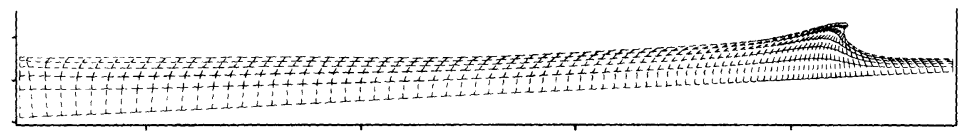

(c) Deformation of elements at $t=2.19 \mathrm{~s}$

Fig. 9 Shoaling of a solitary wave over a $1 / 20$ slope.

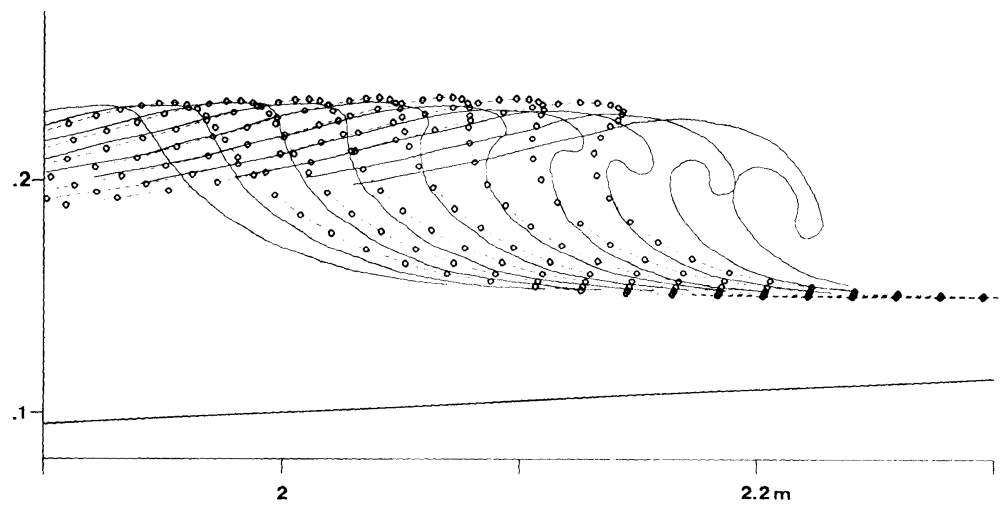

Fig.10 Calculated and observed changes in surface profiles before breaking; time intervals are $18.6 \mathrm{~ms}$ in the computation $(O)$ and $20 \mathrm{~ms}$ in the experiment $(-)$. 


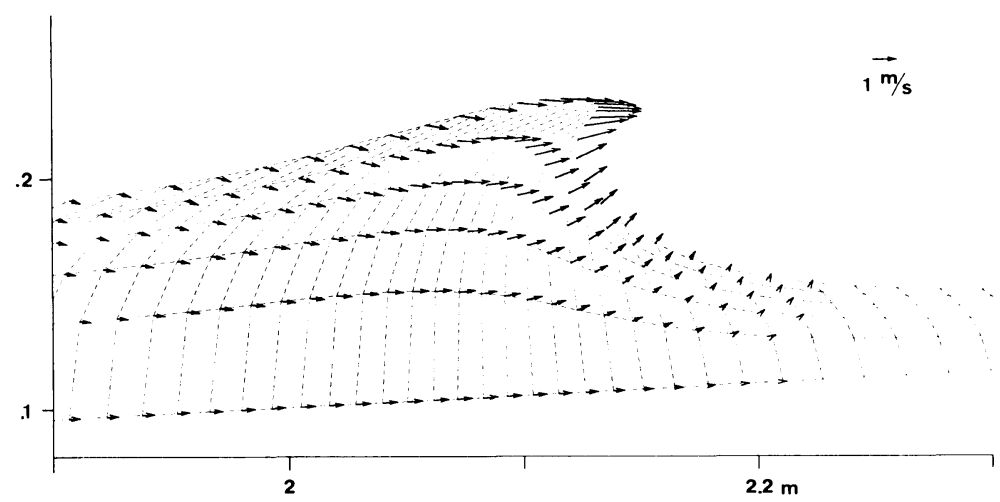

Fig. 11 Field of water particle velocity at $t=2.17 \mathrm{~s}$.

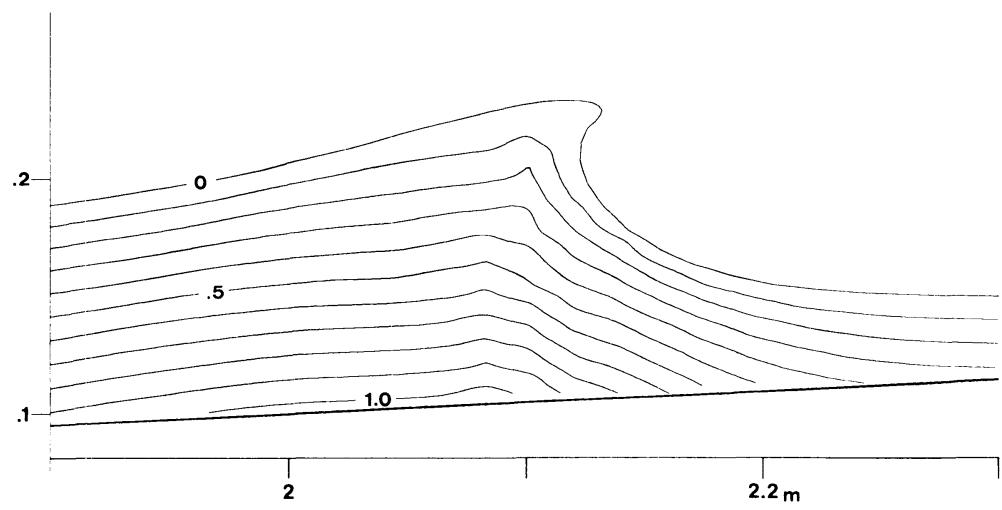

Fig. 12 Isobars at $t=2.17 \mathrm{~s}\left(P / \rho: \mathrm{m}^{2} / \mathrm{s}^{2}\right)$.

められた。

Fig. 11 は砕波点近傍における内部流速の計算值を示 したものである.ここでは，波頂近傍の高流速が特徵的 である.また Fig. 12 には対応する圧力分布を等圧線の 形で示した. 波動の大部分の領域で王力は静水圧分布に 近い状態にある.しかしながら，波頂付近では局地的に 圧力勾配が小さくなっており, 流体間の相互関係が弱 まっていることがわかる.これは気泡の巻き込み等, 砕 波を特徴づける現象の前兆と思われる. 逆に波面直前の 領域では圧力勾配が大きく，底質の巻き上げを容易とす る環境になっている.このケースでは格子数を増し，し たがって時間的にも 3500 ステップの計算を行ったた め, 同一計算機システムによる計算所要時間は約 10 分 と前例の 3 倍程度であった。

Fig. 11 に示した時点以降は, 流体要素の変形が極端 に大きく，計算の続行が不能となる。このような状況下 ではカップリングによる不安定が顕著であり，これを回 避するためには一層精細な計算格子が要求される.

\section{6. 結 語}

本論文では Lagrange 流の表記に基づく波動の数值解
析の具体的な手法について述べてきた，流速を未知量と する流速解法は, 非回転性の波動を解析するうえで有力 な計算手法である.これに対して，圧力を未知量とする 圧力解法はより汎用的であり, 計算時間も節減されるが, 任意境界形状の問題に向けてはさらに検討が必要であ る.

\section{参 考文 献}

1）西村仁嗣・武若 聡：Lagrange 表記による表面波動の数 值解析, 第 33 回海岸工学講演会論文集, pp. 95 98, 1986.

2) Nishimura, H. and Takewaka, S. : Numerical analysis of surface waves using Lagrangian description, Coastal Engineering. in Japan, Vol. 30, pp. 1 7, 1987.

3) Nishimura, H. and Takewaka, S. : Numerical analysis of wave motion using the Lagrangian description, Proc. IUTAM Symposium on Non-linear Water Waves, Tokyo, 1988 (in print).

4) Longuet-Higgins, M.S. and Cokelet, E. D. : The deformation of steep surface waves on water. I. A numerical method of computation, Proc. Roy. Soc. London, A350, pp. 1 26, 1976.

5) Peregrine, D. H. : Recent developments in the modelling of unsteady and breaking water waves, Proc. IUTAM Symposium on Non-linear Water Waves, 
Tokyo, 1987 (in print).

6) たとえば, Miyata, H. : Finite difference simulation of breaking waves, J. Comp. Phys., Vol.65, pp.179 $214,1986$.

7) たとえば, Kawahara, M., Ramaswamy, B. and Anjyu, A. : Lagrangian finite element method for wave motion using velocity correction method, Proc. JSCE, No. 369/II-5, pp. 203 211, 1986.

8) Brennen, C. : Some numerical solutions of unsteady free surface wave problems using the Lagrangian description of the flow, Lecture Notes in Physics 8, Springer Verlag, 1970.

9) Hirt, W. C., Cook, J. L. and Butler, T. D. : A Lagrangian method for calculating the dynamics of an incompressible fluid with free surface. J. Comp. Phys.,
Vol. 5, pp. 103 124, 1970.

10) Chan, R. K. C. : A generalized arbitrary LagrangianEulerian method for incompressible flows with sharp interfaces, J. Comp. Phys., Vol.17, pp. 311 331, 1975.

11）高山知司：振動外力を受けるタンク内発生波の非定常解 について, 運輸省港湾技術研究所報告, 第 15 巻 2 号, pp. 3 53, 1976.

12) Nakayama, T. : Boundary element analysis of nonlinear water wave problems, Int. J. Num. Meth. Eng., Vol. 19, pp. 953 970, 1983.

13）長尾昌朋：斜面上の波の変形に関する研究, 東北大学修 士論文, 121 p. , 1986.

(1987.10.15 - 受付) 